\title{
MicroscopyEducation
}

\section{Lecturing on Microscopy}

\author{
Brian J. Ford \\ Gonville \& Caius College, Cambridge University, Trinity Street, \\ Cambridge CB2 1TA, England
}

brianjford@cardiff.ac.uk

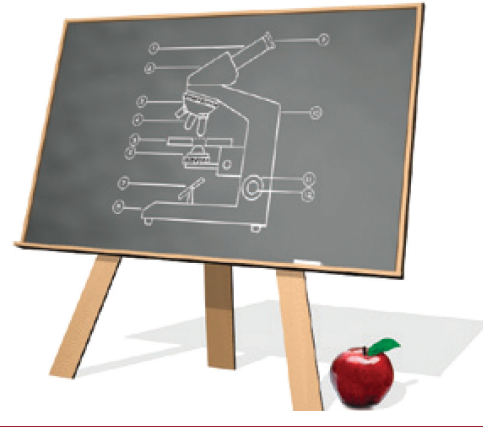

Abstract: In today's media-filled world many people insist that that the traditional lecture is no longer of interest. However, with microscopy as the primary subject, this author believes that there are always great stories to tell. One of those topics, microorganisms, has fascinated scientists and laypeople for over 300 years. Even in a digital era, a passionate lecture can be interesting, inspiring, and memorable.

\section{Introduction}

With the advent of the Internet and sites like YouTube, the traditional lecture has been dismissed as a dying art. Or is it? There is something intrinsically engaging about hearing someone speak in an auditorium, which derivative media (like television) cannot match. Today's television documentaries are of a supremely high quality that few people could have anticipated a decade ago; their scripts are compiled by teams of experts, and the filming uses every conceivable digital device to tease from a recalcitrant world the most captivating of images. Yet a documentary is soon forgotten. We may remember excerpts, like orcas seizing seals from the beach at the Valdes Peninsula in Patagonia (though I daresay you did not recall the place), and there are iconic sequences every child knows-a falling drop of water as it lands, greatly slowed down, or the unfolding petals of a blossom, greatly speeded up.

Yet we can all recall a lyrical lecturer, or an enthusiastic teacher from our childhood. Many professionals and academics will say it was a teacher or lecturer who originally inspired them to pursue their careers. There is something memorable about a live performance that no TV documentary or film can ever match.

\section{Start Young}

Speaking to an audience fills every speaker with a sense of anxiety. It is meant to. If there is no apprehension or fear of failure, then there is little incentive to succeed. In my younger days I was impressed by lessons at school given by my tutor Dr. A. G. Lowndes, a distinguished research biologist who came to King's School, Peterborough, UK, on secondment for a year. Sir Peter Medawar, who won a Nobel Prize for his research on immunology and was also taught by Lowndes, described him as "knowing how to inspire" the students in his class, an effect that lasts a lifetime. I gave my first lectures when still a schoolboy and always tried to link what I was explaining to the familiar, everyday experiences of my audience whether they were laypeople or specialists. Scores of early posters and photographs went missing as we moved house decades ago, though notes for a lecture I gave when aged 16 surfaced just as this article was being compiled. Even then, I was trying to explain phenomena in a vernacular manner that engaged the audience. Yes, the notes remind me how embarrassingly naïve one used to be; and while I would not wish publicly to repeat them, they do embody a recognition of sympathy with the audience. This trait, I am certain, was derived by my lessons with Dr. Lowndes. The typically illegible schoolboy writing says this (Figure 1):

Some years ago at P'boro [Peterborough] we grew Mucor. Interested, grew more. Died until lecture @Cardiff in Sept.

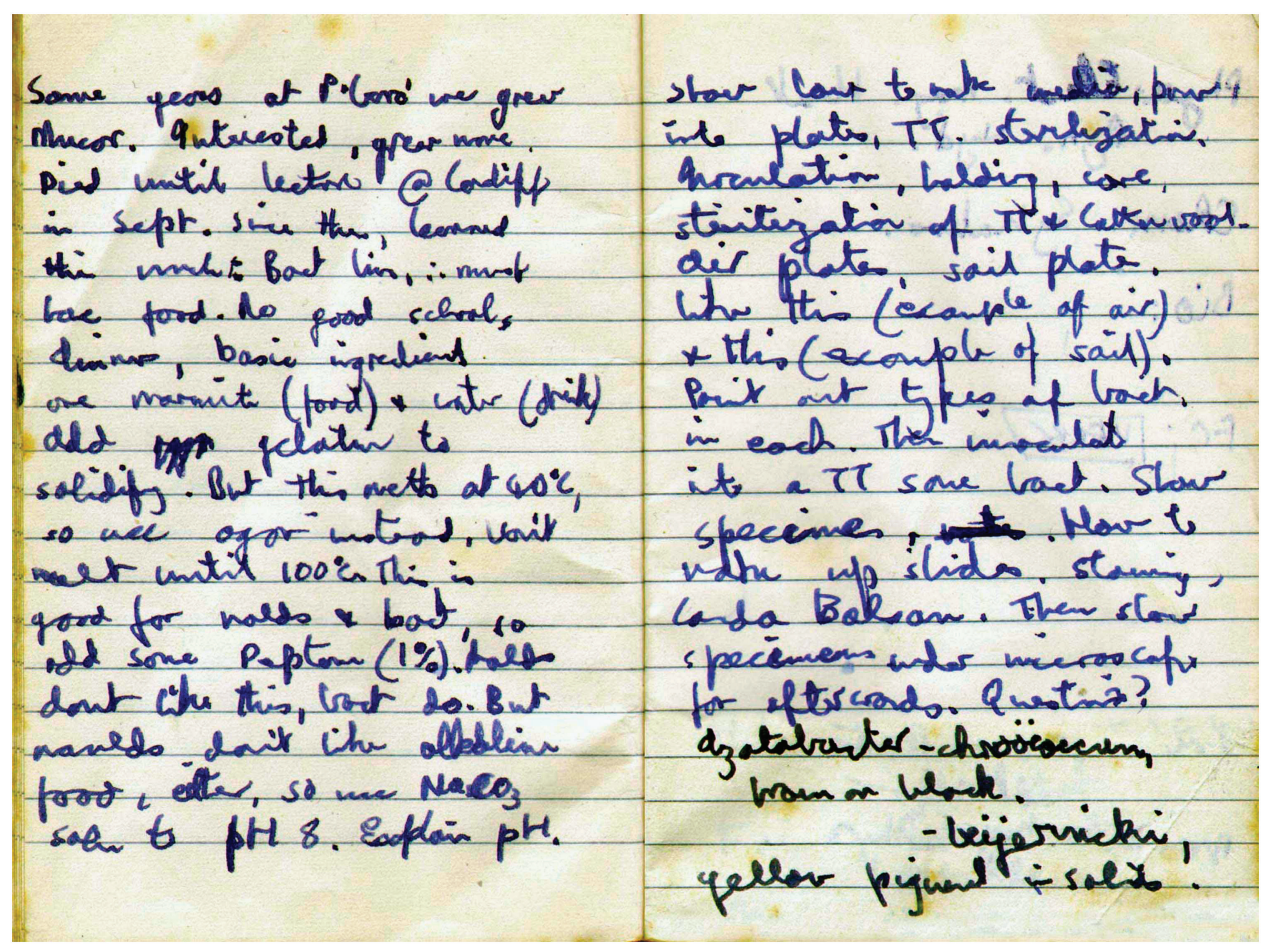

Figure 1: Recently unearthed are lecture notes from one of my earliest presentations. Though sketchy (and not noted for grammar or literary flow), they embody the approach of a 16-year-old speaker to the audience. 


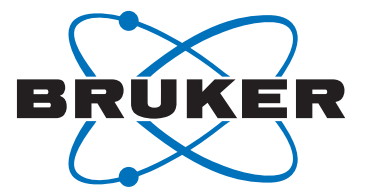

\section{QUANTAX EBSD - Featuring} OPTIMUS ${ }^{\mathrm{TM}}$ TKD, ARGUS ${ }^{\mathrm{TM}}$, ESPRIT QUBE and Picolndenters ${ }^{\circledR}$
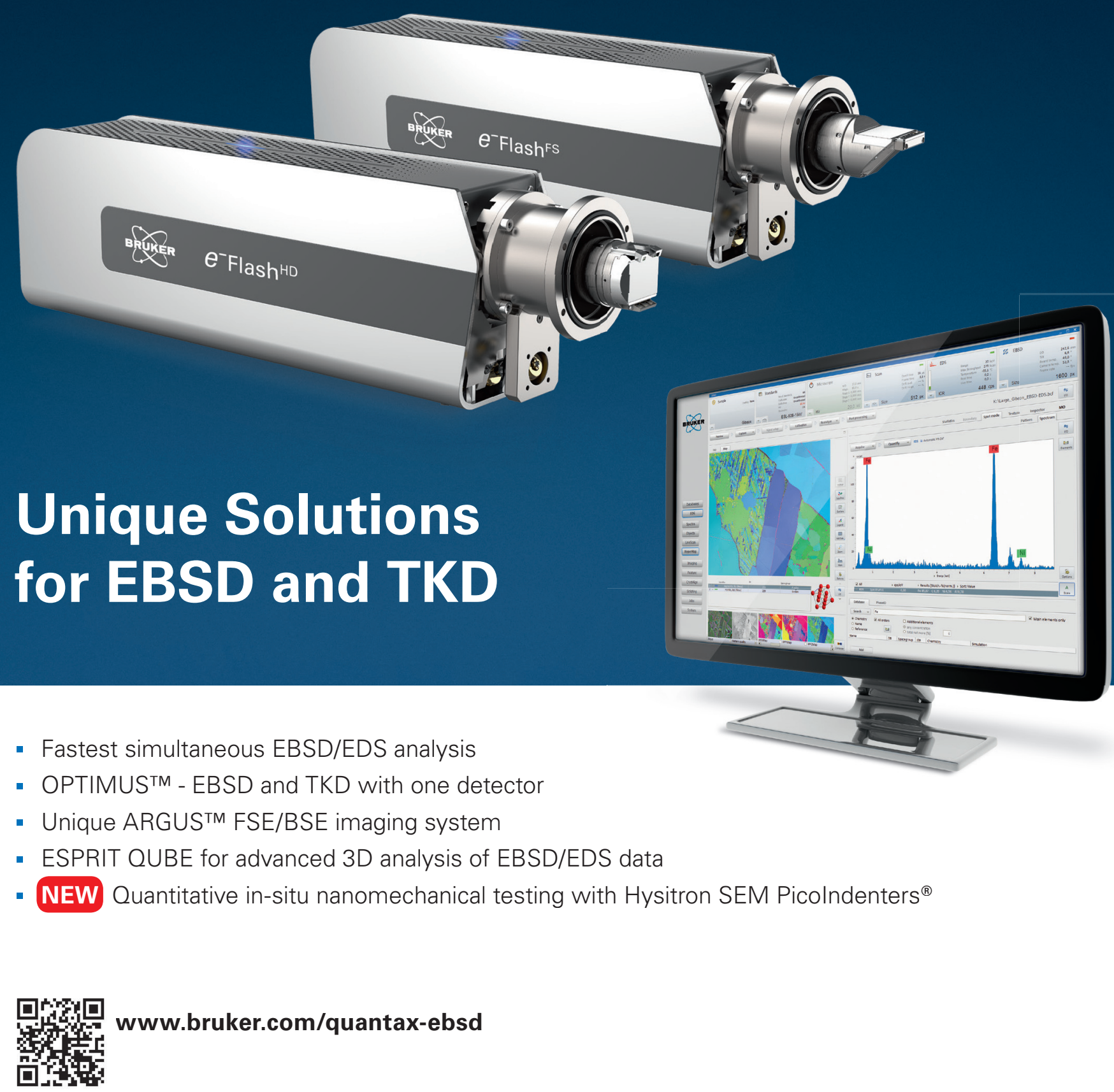

Innovation with Integrity 


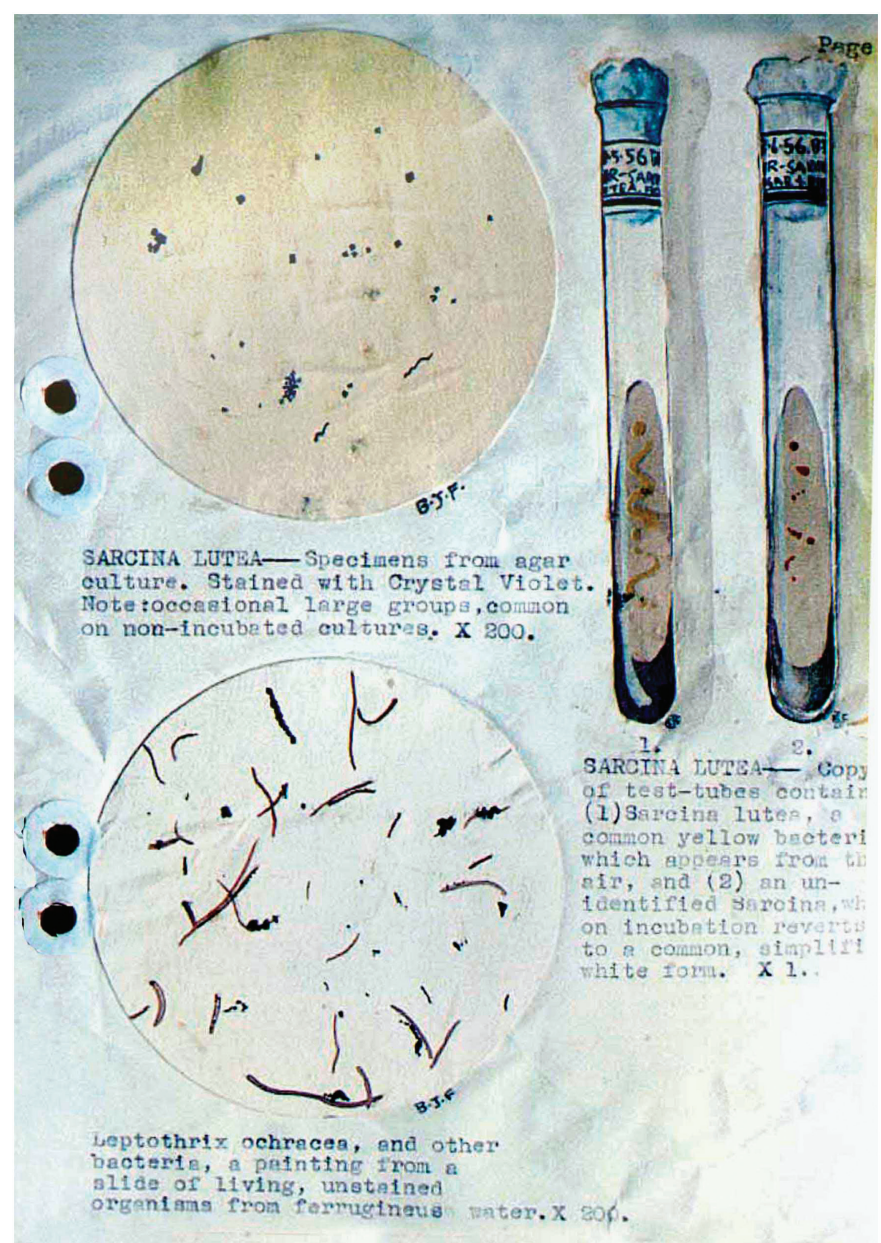

Figure 2: After the lecture, the audience was invited to review a series of small posters summarizing the subject. This is the only surviving photograph of those early watercolor studies that portrayed microorganisms.

Since then, learned this much: bact. [bacteria] live, $\therefore$ [therefore] must have food. No good school dinners, basic

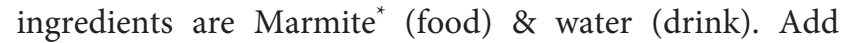
gelatin to solidify. But this melts at $40^{\circ} \mathrm{C}\left[104^{\circ} \mathrm{F}\right]$ so use agar instead, won't melt until, $100^{\circ} \mathrm{C}\left[212^{\circ} \mathrm{F}\right]$. This is good for molds \& bacteria, so add some peptone (1\%). Molds don't like this, bacteria do. But molds don't like alkaline food, either, so use $\mathrm{Na}_{2} \mathrm{CO}_{3}$ soln [solution] to $\mathrm{pH}$ 8. Explain $\mathrm{pH}$. Show how to make media, pour into plates, TT [test-tubes]. Sterilization. Inoculation, holding, care, sterilization of test-tubes \& cottonwool. Air plates, soil plates, like this (example of air) \& this (example of soil). Point out types of bacteria in each. Then inoculated into a test-tube some bacteria. Show specimens. How to make up slides. Staining, Canada balsam. Then show specimens under microscope for afterwards. Questions?

Azotobacter -chroöcoccum, brown or black.

-beijerinckii, yellow pigment in solids.

As a crash-course demonstration of how bacteria are selectively cultured, this still makes some sense (Figure 2).

${ }^{\star}$ Marmite is a nutritious savory spread made from autolyzed yeast cells and a by-product of the brewing industry in Britain.

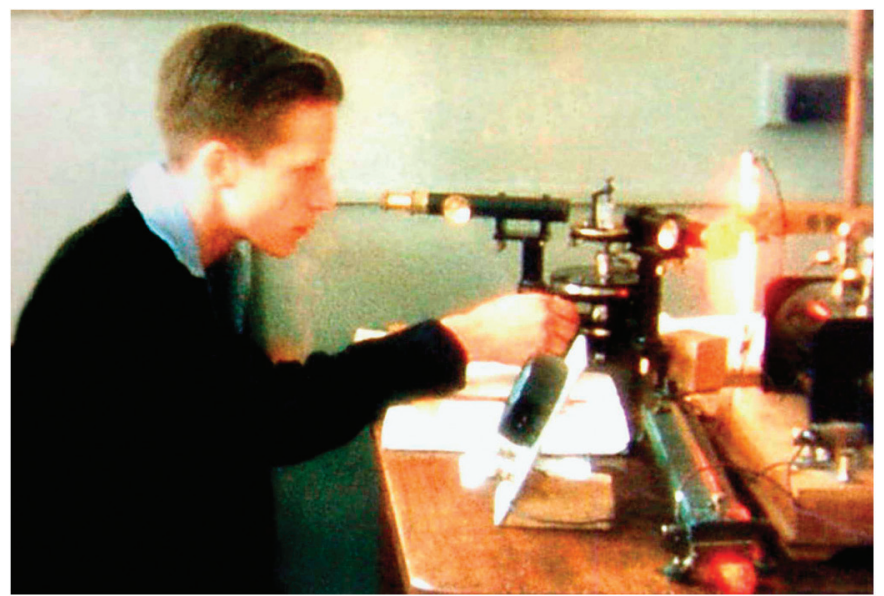

Figure 3: An enduring fascination with research using a range of optical instruments emerges from investigations with a spectroscope carried out as a teenager in this photograph dating from 1956.

There are no other reminders of those early lectures, though there is a hazy photograph of my working with a school spectroscope (Figure 3). There was a single continuing thread to my reasoning at that time-it is the public who pay for science and yet know relatively little about it. They "pay" in both senses: directly or indirectly, they finance everything we do, and-when the resonances impact the public arena-they endure its consequences. If we are embarking on a scientific career, it seemed to me incumbent on us all to devote time to explaining what goes on. That is why, even before I was a university student, I was writing a newspaper column entitled "Science and You." One of the first was on bacteria, which described how ubiquitous they are. That article ended with words that still ring true today, more than fifty years later:

Penicillin was the first antibiotic to be discovered. Bacteria do not give up easily and are now able to resist the drugs. Today the problem is to discover new antibiotics as fast as the bacteria overcome the old drugs [1].

\section{Student Lectures}

Whenever a new acquaintance knows that you used to lecture, they assume it was to a college or university. Student audiences are always enjoyable, I concede. The keen-eyed, sharp-brained Asian audiences I encounter when I lecture in India or Singapore are such enjoyable communities with whom to engage. I have never forgotten the first students I spoke to in the United States (back in 1970), all keen to understand and eager to learn. But being a tenured university lecturer has never appealed to me. For two years, I delivered a course on science for art undergraduates at what is now the Newport Campus at the University of South Wales, and I remember the students to this day. Indeed, some kept in touch for decades after they had qualified (Figures 4 and 5). My eagerness was to discuss new ideas and to embrace fresh challenges, so repeating a course each year and being confined by a syllabus that had been set by some distant and unaccountable authority, was no encouragement.

I frequently lecture to student audiences today and always relish the prospect, though these are one-off presentations. The annual rotation has never appealed. 


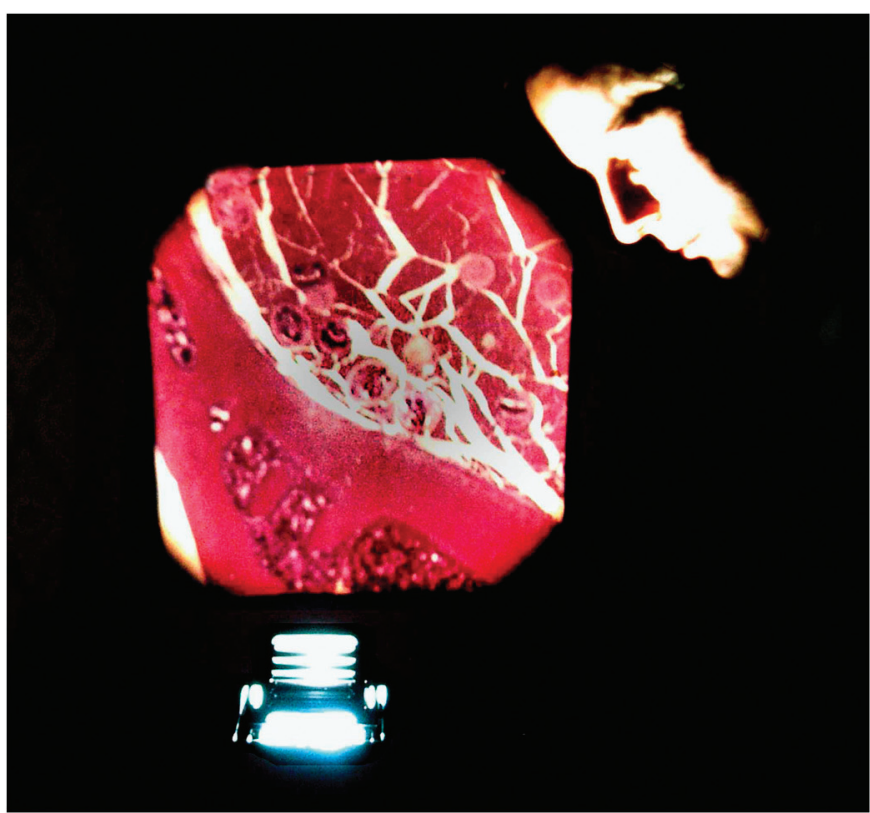

Figure 4: Most members of a present-day audience can hardly recall the $35 \mathrm{~mm}$ slide projector, prone to jamming and bulb failure at inopportune moments. The specimen here is the pork nematode Trichinella.

\section{Academics}

Speaking to students or to the public is an exacting science. Each unfamiliar term has to be explained, and every process or phenomenon linked, as far as possible, to what the listeners may themselves have experienced. For an academic audience, these problems evaporate. They are already familiar with the field, and they understand the ground rules. The need for clarity is aided by their understanding of the specialist terms with which the subject is described.

I have always enjoyed addressing a learned audience, my first such lecture in London being to a conference on blood circulation organized by the British Microcirculatory Society for the Royal Microscopical Society in 1965, which took place in the august surroundings of the Royal Society of London (Figure 6). That was in Burlington House, Piccadilly, and, as I spoke, the intimidating gaze of King Charles II peered down intently from the seventeenth-century portrait attributed to Peter Lely. Whenever I am at the Royal Society today, now ensconced in Carlton House Terrace, the same portrait hangs above us, and I am reminded of that occasion. The lecture attracted media attention and was widely reported in the press. The audience members were tolerant of a young upstart, and some of them speak kindly of the presentation to the present day [2].

This is the thrust of a lecture-people do remember it with more interest and greater commitment than they will ever recall a television program. For academic speakers, the aim is to be clear and concise, and one should never, no matter what happens, go over your allotted time. I have sometimes said, to someone due to chair a lecture, that you need not tell the speaker how long they have to speak. They will forget. The occasion will overwhelm them and they'll lose track of time. Instead, emphasize the precise time when they

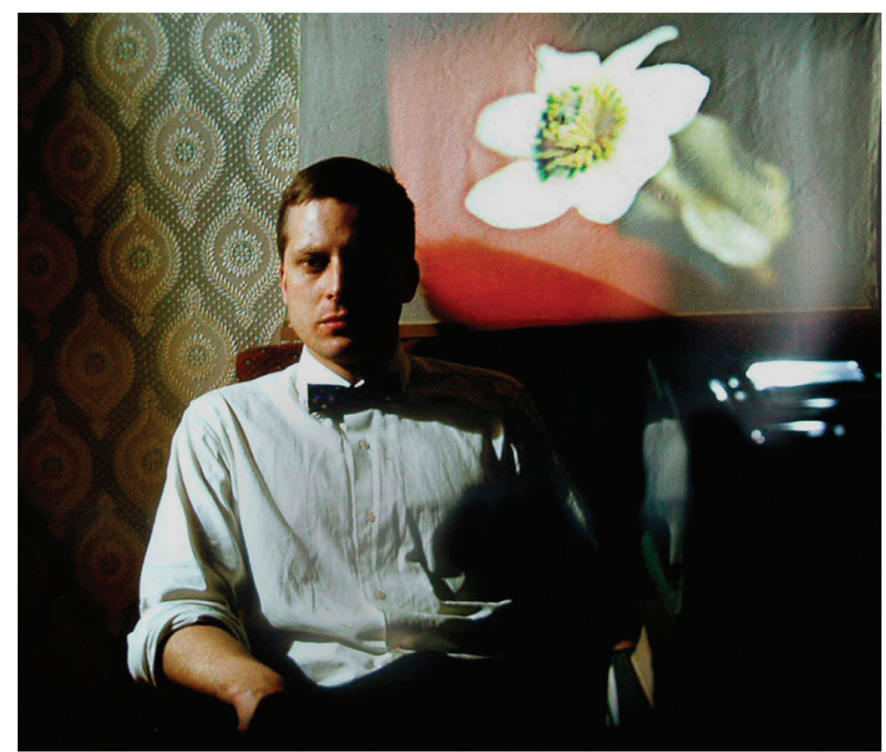

Figure 5: Running through slides for a lecture on botany at home in 1964, with post-WWII wallpaper and a primitive screen. The $35 \mathrm{~mm}$ slide carousels held 120 slides. Sometimes more than one was needed for a talk.

must stop. If this is 3:30 p.m. they will creep toward it minute by minute and are much less likely to abuse the hospitality of the podium. I have been in the audience several times when a guest lecturer spoke for over an hour in a twenty-minute slot. They are not invited back.

\section{The Public and the Microscope}

If I could pass just one single law governing education, it would be this: no child should ever reach the age of ten without seeing aquatic microorganisms through a microscope. Leeuwenhoek, when he first described protozoa in a letter dated September 7, 1674, wrote how their movement was "so swift, and so various, upwards, downwards and round-about, that 'twas wonderful to see ..." [3].

I have always enjoyed showing youngsters what the microscope reveals, and lecturing to an adult audience gives a chance to bring them sights they will not find anywhere else. Television companies are remarkably disinterested in the microscopical world; the argument is that there is no evidence of public interest in the topic, a self-perpetuating opinion that has circulated ever since Liza discovered that there really was a hole in that bucket. The BBC has a global reputation for showing "every kind of living creature," yet they never address microbes. Their previous Director-General, Mr. Mark Thompson, whom I knew from his days as the CEO of Channel Four TV in London, once invited me to submit an outline for a series of microscope documentaries. The document disappeared until he intervened some months later, and we were told by their commissioning editor that the BBC would not consider a series and would need to have any such program made by an outside contractor. Though disappointed, I was not in the least surprised when they soon began to work on this series in their own way. It embraced much of my own research, but because they lacked video technicians with a knowledge of the microscope, the results were disappointing. 


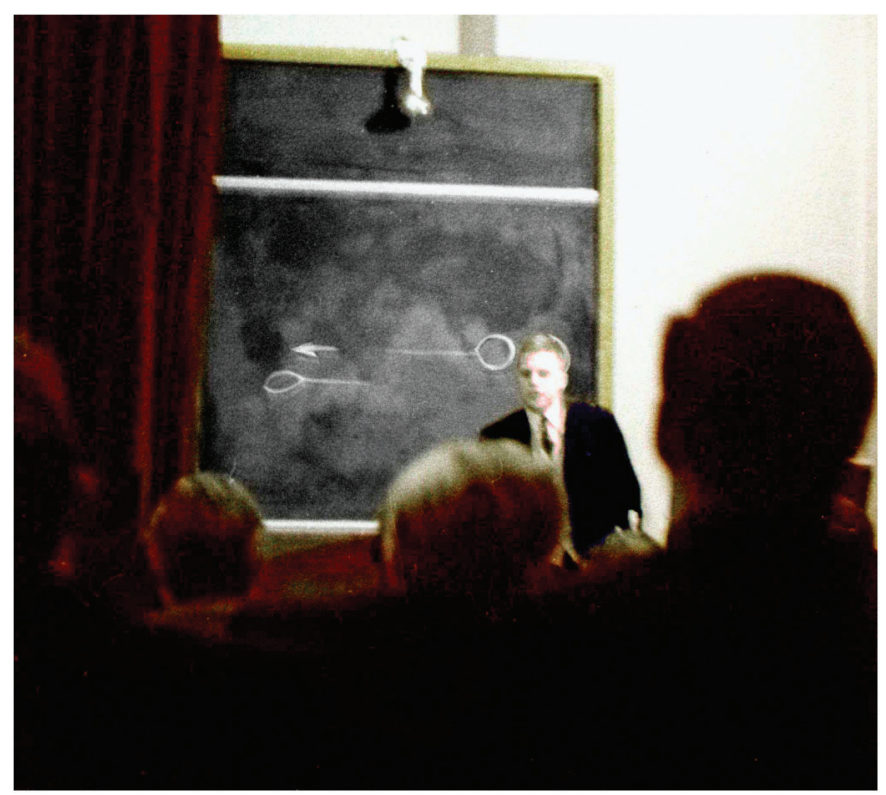

Figure 6: The Royal Society hosted a meeting in London in February 1965 that included my first lecture in London. It was reported in the press and later featured in the McGraw-Hill Annual Yearbook of Science and Technology.

Many people raised the issue with me, and thought I should be deeply offended and personally affronted by it all. I was not, of course; those lamentable documentaries provide wonderful material for my lectures, and they have featured prominently in my presentations ever since. Delivering a lecture that shows the marvelous antics of microbes is a continuing joy, and-when you can illustrate the point with examples from programs that show how not to do it-then the point goes home in a particularly memorable fashion.

In 1969, Professor Walter McCrone invited me to lecture at the Inter/Micro conference held that year at Imperial College, London. I spoke on new observations of

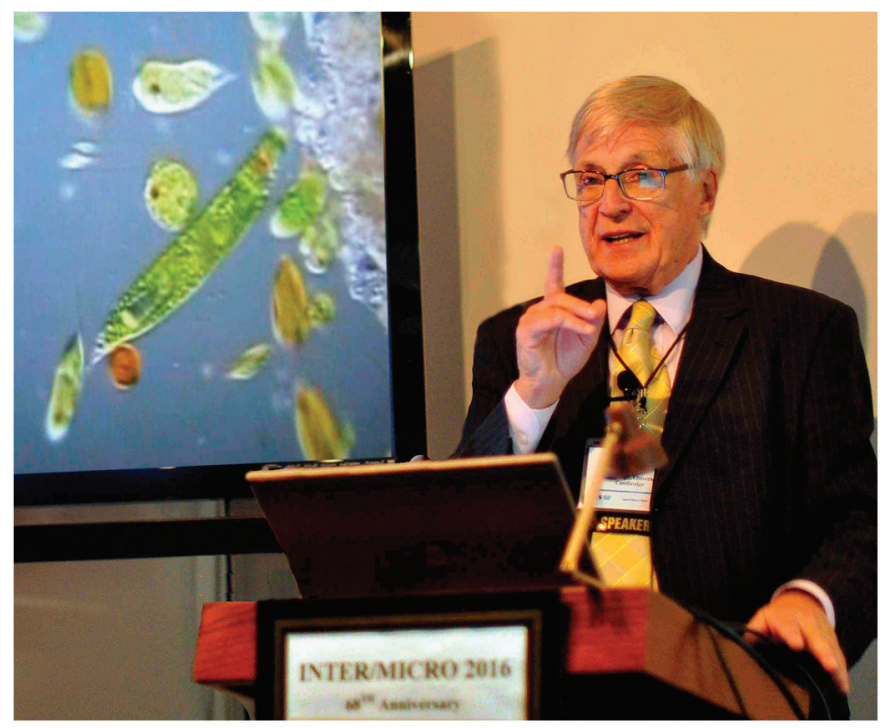

Figure 7: A presentation entitled "Magical Mystery Tour of the Cell" was my 97th lecture to the Inter/Micro conference in Chicago. In June of 2017 I presented my 100 th lecture to that meeting. (Dean Golemis/McCrone Research Institute) the phenomena of hemostasis and included in my talk some of my $16 \mathrm{~mm}$ movies that illustrated the point. I enjoyed the event, and the audience were wonderfully tolerant. I lectured at the Inter/Micro conference at Cambridge UK through the 1970s, until 1984 when my research presentations were supplemented by a personal evening lecture on the Monday evening each year. McCrone later dubbed them "An Evening with Brian," and they have continued since. The total of all my talks at Inter/Micro has now passed 100, and each one brought a chance to explore new ground (Figure 7). Many gave rise to papers, and some to books.

For the past fifteen years I have also been invited to join cruise ships as their guest speaker, and often I present the magical world that the microscope reveals. This is a chance to show the marvels that the public never sees, and I can supplement the story with the discoveries of brilliant microscopists whose work everyone should experience.

\section{Speaking to Societies}

Here you face an audience of enthusiasts. They know what you are talking about before you utter your first word. The many microscopical societies in the United States embrace some of the keenest minds in the world, and they are always a pleasure to address. Indeed, it is an honor to be asked. I have also lectured to specialty audiences at Cambridge University, where you can find a clutch of Nobel Prize winners in the audiences. Speaking to fellow travelers is uniquely exciting, and you stand to learn as much as you convey. Some of you may recall that I was plenary speaker at Microscopy \& Microanalysis 2014, held in Hartford, Connecticut (Figure 8). The vast audience was young, enthusiastic, and hungry for knowledge [4].

And why not? What I present is the wonders we see through our microscopes. It is the microbes that star in those presentations, for it would be hard to give a drab talk when the subjects are so dynamic, so intensely visible, and so surprisingly unfamiliar.

Conference lectures are a perpetual preoccupation, of course; though they are often a formality when the audience is already familiar with what a speaker is going to present. Conference proceedings are regularly published, though their purpose is of diminishing relevance in the era of the Internet. In my view, it would be far more interesting

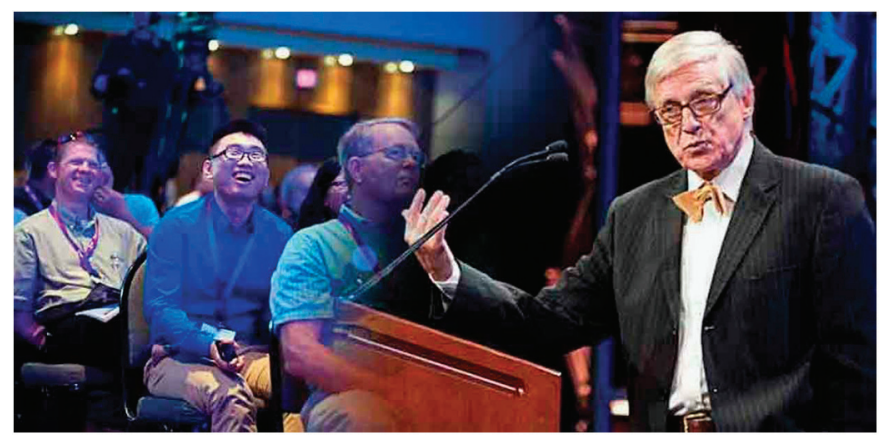

Figure 8: A young and eager audience attended the plenary talk at the Microscopy \& Microanalysis congress held in Hartford, Connecticut, in 2014. Microscopists, of course, are always the easiest audience to address. 
to publish the proceedings of what was said in the bar. That's where the major discussions always take place.

\section{Successful Lectures}

The lecture is not dead. People who decry them are merely responding to bad lecturers. I would encourage every microscopist to speak about their passion. Abandon the clichéd blue background of the standard PowerPoint presentation and opt for something different. Keep words off the screen; they should come from your heart, and the pictures and videos should supplement what you say. And I should add the advice once given to me by a great British humorist, Basil Boothroyd. He said to me, "First, have an amusing start. Secondly, make the ending memorable. And thirdly-this is the most important rule of all-make sure you keep both of those really close together."

\section{Conclusion}

Please be encouraged to lecture. Speak with conviction. Let the microbes tell their story. And never go over your time.

\section{References}

[1] BJ Ford, "Science and You: Bacteria," South Wales Echo, October 23, 1959.

[2] BJ Ford, The Microscope 59(4) (2011) 165-73.

[3] C Dobell, Antony van Leeuwenhoek and his "Little Animals," John Bale, Sons \& Danielsson, London, 1932, p. 111.

[4] J Heath and C Parmenter, Microsc Microanal 20(5) (2014) 22.

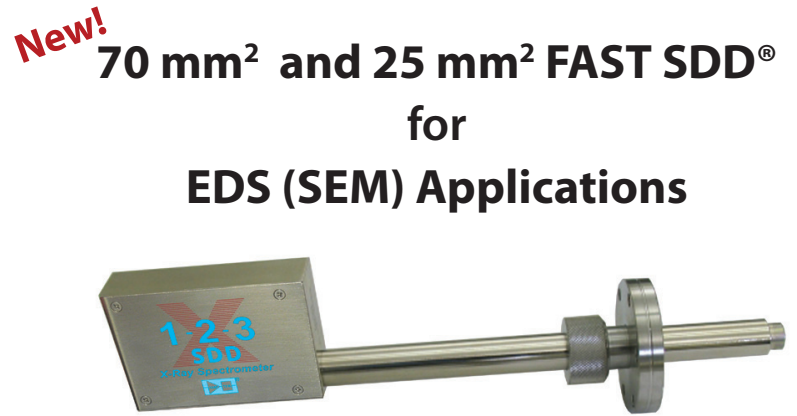

Amptek's new FAST SDD ${ }^{\circledR}$ detectors for EDS use with SEMs utilize "C2 Series" X-ray windows $\left(\mathrm{Si}_{3} \mathrm{~N}_{4}\right)$ and have excellent low energy response. Its high intrinsic efficiency makes it ideal for EDX, XEDS, EDXA and EDXMA.
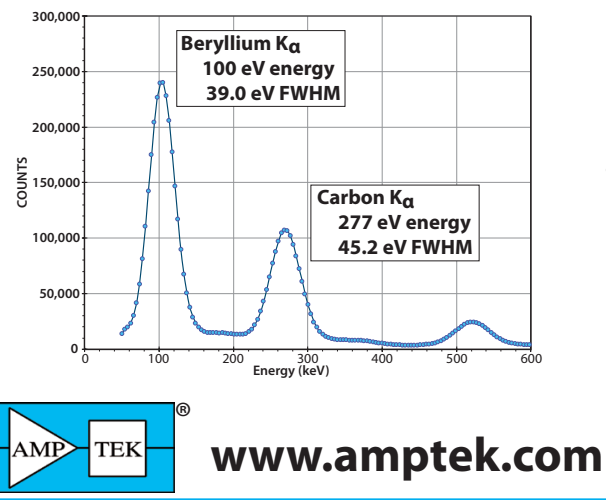

OEM's \#1 Choice

NMETEK

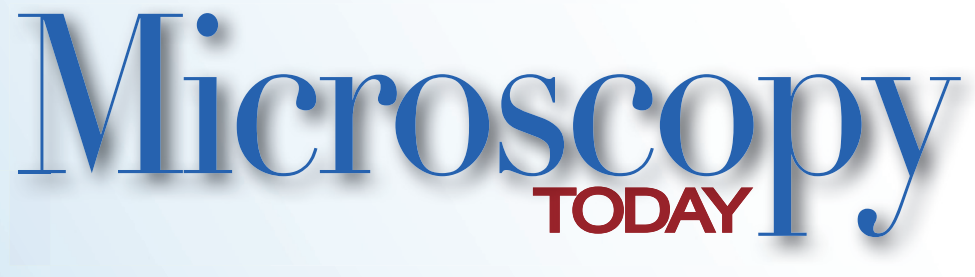

\section{Innovation Awards}

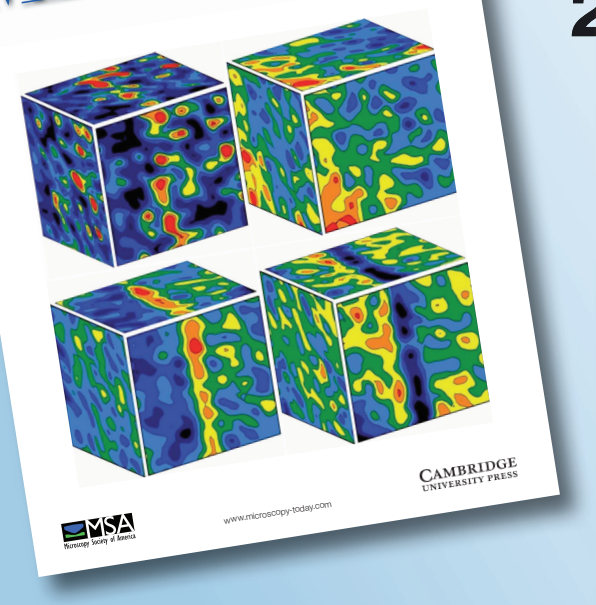

Entry deadline is March 21, 2018

Application forms are available at www.microscopy-today.com 